\title{
Addition of $\mathrm{Bu}_{3} \mathrm{SnLi}$ to $t$-Butanesulfinimines as an Efficient Route to Chiral, Non-racemic $\alpha$ -
}

\section{Aminoorganostannanes}

\author{
Kevin W. Kells and J. Michael Chong* \\ Guelph-Waterloo Centre for Graduate Work in Chemistry and Biochemistry, $(G W C)^{2}$ \\ Department of Chemistry, University of Waterloo, Waterloo, Ontario, Canada \\ $N 2 L 3 G 1$
}

\section{Supporting Information}

\section{General Experimental}

All reactions were performed using flame-dried glassware under an argon atmosphere. Diethyl ether and THF were freshly distilled from Na/benzophenone. $(R)$ - and $(S)$-t -butanesulfinamide were prepared from the appropriate cis-1-amino-2-indanol as reported by the Sepracor group. ${ }^{1}{ }^{1} \mathrm{H}$ and ${ }^{13} \mathrm{C}$ NMR spectra were recorded in $\mathrm{CDCl}_{3}$ at 300 and $75 \mathrm{MHz}$, respectively. Optical rotations were recorded in cells with $10 \mathrm{~cm}$ path length on a Perkin-Elmer 241 digital polarimeter.

General procedure for synthesis of enantiomerically pure sulfinimines 4. t-Butanesulfinimines were prepared by condensation of $(R)$ - or $(S)$-t-butanesulfinamide with aldehydes as described by

Ellman. $^{2}$ Our $(R)-t$-butanesulfinamide showed $[\alpha]_{\mathrm{D}}=+4.6\left(\right.$ c $\left.0.8, \mathrm{CHCl}_{3}\right) ;$ lit $^{2}:[\alpha]_{\mathrm{D}}=+4.9(\mathrm{c}$ 1.0, $\left.\mathrm{CHCl}_{3}\right)$. Our $(S)$-t -butanesulfinamide showed $[\alpha]_{\mathrm{D}}=-5.1\left(\mathrm{c} 0.6, \mathrm{CHCl}_{3}\right)$. Spectral data are as follows: 
$\left(S_{\mathrm{S}}\right)-N$-(Ethylidene)-t-butanesulfinamide $(4 a)^{3}$

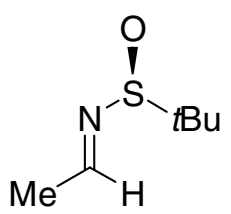

$[\alpha]_{\mathrm{D}}=-94.8\left(\mathrm{c} 1.0, \mathrm{CHCl}_{3}\right) ;{ }^{1} \mathrm{H} \mathrm{NMR}\left(300 \mathrm{MHz}, \mathrm{CDCl}_{3}\right) \delta 7.94(1 \mathrm{H}, \mathrm{q}, \mathrm{J}=5.1 \mathrm{~Hz}), 2.34(3 \mathrm{H}, \mathrm{d}, \mathrm{J}=$ $5.1 \mathrm{~Hz}), 1.09(9 \mathrm{H}, \mathrm{s}) ;{ }^{13} \mathrm{C}$ NMR $\left(75 \mathrm{MHz}, \mathrm{CDCl}_{3}\right) \delta 165.8,56.3,55.0,22.1$.

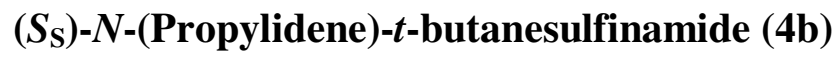<smiles>[10BH2]/S(O)=N\CC</smiles>

$[\alpha]_{\mathrm{D}}=+294.6\left(\mathrm{c} 1.0, \mathrm{CHCl}_{3}\right)$, lit for $\left(R_{\mathrm{S}}\right)-4 \mathrm{~b}^{2}[\alpha]_{\mathrm{D}}=-328.5\left(\mathrm{c} 1.0, \mathrm{CHCl}_{3}\right) ;{ }^{1} \mathrm{H} \mathrm{NMR}(300 \mathrm{MHz}$, $\left.\mathrm{CDCl}_{3}\right) \delta 7.94(1 \mathrm{H}, \mathrm{t}, \mathrm{J}=4.2 \mathrm{~Hz}), 2.39(2 \mathrm{H}, \mathrm{dq}, \mathrm{J}=7.4,4.2 \mathrm{~Hz}), 1.04(9 \mathrm{H}, \mathrm{s}), 1.03(3 \mathrm{H}, \mathrm{t}, \mathrm{J}=7.4 \mathrm{~Hz})$;

${ }^{13} \mathrm{C}$ NMR $\left(75 \mathrm{MHz}, \mathrm{CDCl}_{3}\right) \delta 169.9,56.1,29.2,22.0,9.3$.

$\left(S_{\mathrm{S}}\right)-N$-(Isobutylidene)-t-butanesulfinamide $(4 \mathrm{c})$<smiles>CCC=NS(=O)O</smiles>

$[\alpha]_{\mathrm{D}}=+299.9\left(\mathrm{c} 1.0, \mathrm{CHCl}_{3}\right), \mathrm{lit}^{2}$ for $\left(R_{\mathrm{S}}\right)-4 \mathrm{c}:[\alpha]_{\mathrm{D}}=-259.4\left(\mathrm{c} 1.0, \mathrm{CHCl}_{3}\right) ; ;{ }^{1} \mathrm{H}$ NMR $(300 \mathrm{MHz}$, $\left.\mathrm{CDCl}_{3}\right) \delta 7.91(1 \mathrm{H}, \mathrm{d}, \mathrm{J}=4.4 \mathrm{~Hz}), 2.64(1 \mathrm{H}, \mathrm{dsept}, \mathrm{J}=6.9,4.4 \mathrm{~Hz}), 1.11(9 \mathrm{H}, \mathrm{s}), 1.05(3 \mathrm{H}, \mathrm{d}, \mathrm{J}=6.9$ $\mathrm{Hz}), 1.04(3 \mathrm{H}, \mathrm{d}, \mathrm{J}=6.9 \mathrm{~Hz}) ;{ }^{13} \mathrm{C} \mathrm{NMR}\left(75 \mathrm{MHz}, \mathrm{CDCl}_{3}\right) \delta 173.4$ 56.3, 34.7, 22.2, 18.8.

$\left(S_{\mathrm{S}}\right)-N$-(Neopentylidene)- $t$-butanesulfinamide $(4 \mathrm{~d})$<smiles>O=C(Br)N=S(O)CBr</smiles> 
$[\alpha]_{\mathrm{D}}=+104.3\left(\mathrm{c} 1.0, \mathrm{CHCl}_{3}\right), \mathrm{lit}^{3}$ for $\left(R_{\mathrm{S}}\right)-4 \mathrm{~d}:[\alpha]_{\mathrm{D}}=-285\left(\mathrm{c} 1.0, \mathrm{CHCl}_{3}\right) ; ;{ }^{1} \mathrm{H} \mathrm{NMR}(300 \mathrm{MHz}$,

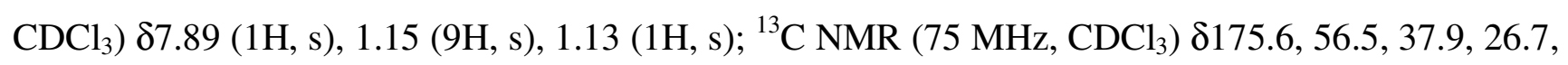
22.3 .

$\left(S_{\mathrm{S}}\right)-N$-(Hexylidene)-t-butanesulfinamide (4e)<smiles>O=S(O)/N=C/c1ccccc1</smiles>

$[\alpha]_{\mathrm{D}}=+240.3\left(\mathrm{c}=1.0, \mathrm{CHCl}_{3}\right) ;{ }^{1} \mathrm{H} \mathrm{NMR}\left(300 \mathrm{MHz}, \mathrm{CDCl}_{3}\right) \delta 8.00(1 \mathrm{H}, \mathrm{t}, \mathrm{J}=4.7 \mathrm{~Hz}), 2.45(2 \mathrm{H}, \mathrm{dt}, \mathrm{J}$ $=7.4,4.7 \mathrm{~Hz}), 1.57(2 \mathrm{H}, \mathrm{m}), 1.28(4 \mathrm{H}, \mathrm{m}), 1.13(9 \mathrm{H}, \mathrm{s}), 0.83(3 \mathrm{H}, \mathrm{m}) ;{ }^{13} \mathrm{C} \mathrm{NMR}\left(300 \mathrm{MHz}, \mathrm{CDCl}_{3}\right)$ $\delta 169.7,56.4,36.0,31.3,25.1,22.3,22.2,13.8$

$\left(R_{\mathrm{S}}\right)-N$-(8-Benzyloxyoctylidene)-t-butanesulfinamide (4f)

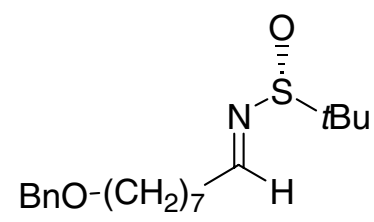

$[\alpha]_{\mathrm{D}}=-142.0\left(\mathrm{c}=1.0, \mathrm{CHCl}_{3}\right) ;{ }^{1} \mathrm{H} \mathrm{NMR}\left(300 \mathrm{MHz}, \mathrm{CDCl}_{3}\right) \delta 8.03(1 \mathrm{H}, \mathrm{t}, \mathrm{J}=4.7 \mathrm{~Hz}), 7.30(5 \mathrm{H}, \mathrm{m})$, $4.46(2 \mathrm{H}, \mathrm{s}), 3.43(2 \mathrm{H}, \mathrm{t}, \mathrm{J}=6.5 \mathrm{~Hz}), 2.47(2 \mathrm{H}, \mathrm{dt}, \mathrm{J}=7.3,4.7 \mathrm{~Hz}), 1.58(4 \mathrm{H}, \mathrm{m}), 1.41-1.27(6 \mathrm{H}, \mathrm{m})$, $1.16(9 \mathrm{H}, \mathrm{s}) ;{ }^{13} \mathrm{C} \mathrm{NMR}\left(300 \mathrm{MHz}, \mathrm{CDCl}_{3}\right) \delta 169.6,138.5,128.2,127.5,127.4,72.8,70.2,56.4,36.0$, 29.6, 29.1, 25.9, 25.3, 22.2 (2C); IR (neat) 1721, 1622, 1363, $1086 \mathrm{~cm}^{-1}$; MS (ESI) $\mathrm{m} / z 338(\mathrm{M}+\mathrm{H})$, $355\left(\mathrm{M}+\mathrm{NH}_{4}\right), 360(\mathrm{M}+\mathrm{Na})$; Anal. Calcd for $\mathrm{C}_{19} \mathrm{H}_{31} \mathrm{NO}_{2} \mathrm{~S}: \mathrm{C}, 67.61 ; \mathrm{H}, 9.26 ; \mathrm{N}, 4.15$. Found: $\mathrm{C}$, 67.36; H, 9.32; N, 4.00 .

$\left(S_{\mathrm{S}}\right)-N$-(Cyclohexylmethylidene)-t-butanesulfinamide $(4 \mathrm{~g})^{4}$

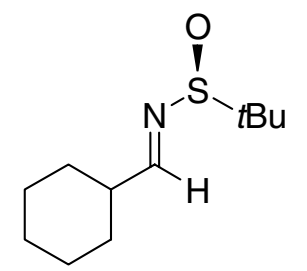


$[\alpha]_{\mathrm{D}}=-173.8\left(\mathrm{c} 1.0, \mathrm{CHCl}_{3}\right) ;{ }^{1} \mathrm{H}$ NMR $\left(300 \mathrm{MHz}, \mathrm{CDCl}_{3}\right) \delta 7.93(1 \mathrm{H}, \mathrm{d}, \mathrm{J}=4.5 \mathrm{~Hz}), 2.43(1 \mathrm{H}, \mathrm{m})$, 1.96-1.55 (5H, m), 1.45-1.23 (5H, m), $1.16(9 \mathrm{H}, \mathrm{s}) ;{ }^{13} \mathrm{C}$ NMR $\left(75 \mathrm{MHz}, \mathrm{CDCl}_{3}\right) \delta 172.5,56.3,43.8$ $29.1,25.7,25.2,22.1$.

General procedure for the synthesis of $\alpha$-sulfinamidostannanes 5. A flame dried round bottom flask equipped with a stir bar and septum was charged with dry THF (10 mL) while being kept under argon. Upon cooling the solution to $0{ }^{\circ} \mathrm{C}$, diisopropylamine $(4.0 \mathrm{mmol}, 1.3 \mathrm{eq})$ was added via syringe, followed by $n$-butyllitihium (1.6 M, $4.0 \mathrm{mmol}, 1.3 \mathrm{eq})$. The solution was stirred for $15 \mathrm{~min}$. at $0{ }^{\circ} \mathrm{C}$. Tributyltin hydride $(4.0 \mathrm{mmol}, 1.3 \mathrm{eq})$ was then added via syringe and the solution stirred for another $15 \mathrm{~min}$. at $0{ }^{\circ} \mathrm{C}$ before cooling to $-78{ }^{\circ} \mathrm{C}$. The sulfinimine $(3.64 \mathrm{mmol})$ was dissolved in dry THF (1 mL) and added dropwise to the stirring solution. Upon completion of the addition, the solution was stirred at $-78{ }^{\circ} \mathrm{C}$ for $1 \mathrm{~h}$. The reaction was quenched cold with methanol $(2 \mathrm{~mL})$, then saturated aqueous ammonium chloride $(5 \mathrm{~mL})$, and allowed to warm to room temperature. The mixture was diluted with diethyl ether $(100 \mathrm{~mL})$ and water $(15 \mathrm{~mL})$, and the ether layer washed with brine $(20 \mathrm{~mL})$, dried with sodium sulfate, and filtered through a pad of Celite ${ }^{\circledR}$. The ether layer was evaporated under reduced pressure to afford a clear colorless oil, which was purified via flash column chromatography (30 g of silica/g of crude material, 5:1 hexane:ethyl acetate) to provide sulfinamides 5 in the yields reported in Table 1.

$\left(S_{S}, R\right)-N$-(1-Tributylstannylethyl)-t-butanesulfinamide (5a)

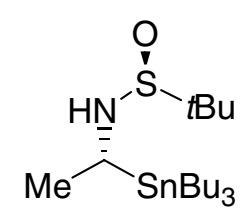

$[\alpha]_{\mathrm{D}}=+51.2\left(\mathrm{c} 1.0, \mathrm{CHCl}_{3}\right) ;{ }^{1} \mathrm{H} \mathrm{NMR}\left(300 \mathrm{MHz}, \mathrm{CDCl}_{3}\right) \delta 3.32(1 \mathrm{H}, \mathrm{dq}, \mathrm{J}=7.4,8.4 \mathrm{~Hz}), 3.02(1 \mathrm{H}, \mathrm{d}$, $\mathrm{J}=8.4 \mathrm{~Hz}), 1.60-1.33(6 \mathrm{H}, \mathrm{m}), 1.49(3 \mathrm{H}, \mathrm{d}, \mathrm{J}=7.4 \mathrm{~Hz}), 1.33-1.18(6 \mathrm{H}, \mathrm{m}), 1.14(9 \mathrm{H}, \mathrm{s}), 0.97-0.75$ $(15 \mathrm{H}, \mathrm{m}) ;{ }^{13} \mathrm{C}$ NMR $\left(75 \mathrm{MHz}, \mathrm{CDCl}_{3}\right) \delta 55.742 .2\left({ }^{1} \mathrm{~J}=347 \mathrm{~Hz}\right), 29.1\left({ }^{2} \mathrm{~J}=20 \mathrm{~Hz}\right), 27.4\left({ }^{3} \mathrm{~J}=54 \mathrm{~Hz}\right)$, 
23.1, 22.6, 13.6, $8.9\left({ }^{1} \mathrm{~J}=315,301 \mathrm{~Hz}\right.$ ); IR (neat) 3436, 3195, 1464, $1056 \mathrm{~cm}^{-1}$; MS (ESI) $\mathrm{m} / z 440$ $(\mathrm{M}+\mathrm{H}), 462(\mathrm{M}+\mathrm{Na})$; Anal. Calcd for $\mathrm{C}_{18} \mathrm{H}_{41} \mathrm{NOSSn}: \mathrm{C}, 49.33 ; \mathrm{H}, 9.43 ; \mathrm{N}, 3.20$. Found: $\mathrm{C}, 49.60 ; \mathrm{H}$, $9.24 ; \mathrm{N}, 3.50$.

$\left(S_{S}, R\right)-N$-(1-Tributylstannylpropyl)-t-butanesulfinamide (5b)

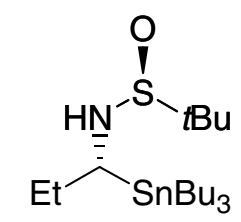

$[\alpha]_{\mathrm{D}}=+35.1\left(\mathrm{c} 1.0, \mathrm{CHCl}_{3}\right) ;{ }^{1} \mathrm{H} \mathrm{NMR}\left(300 \mathrm{MHz}, \mathrm{CDCl}_{3}\right) \delta 3.27(1 \mathrm{H}, \mathrm{m}), 3.14(1 \mathrm{H}, \mathrm{d}, \mathrm{J}=8.5 \mathrm{~Hz})$, $1.83(2 \mathrm{H}, \mathrm{m}), 1.55-1.32(6 \mathrm{H}, \mathrm{m}), 1.30-1.17(6 \mathrm{H}, \mathrm{m}), 1.12(9 \mathrm{H}, \mathrm{s}), 0.92-0.78(18 \mathrm{H}, \mathrm{m}) ;{ }^{13} \mathrm{C} \mathrm{NMR}(75$ $\left.\mathrm{MHz}, \mathrm{CDCl}_{3}\right) \delta 55.849 .9\left({ }^{1} \mathrm{~J}=344 \mathrm{~Hz}\right), 29.6,29.1\left({ }^{2} \mathrm{~J}=20 \mathrm{~Hz}\right), 27.4\left({ }^{3} \mathrm{~J}=57 \mathrm{~Hz}\right), 22.6,13.5,12.4$, $9.4\left({ }^{1} \mathrm{~J}=314,300 \mathrm{~Hz}\right)$; IR (neat) 3198, 1464, $1056 \mathrm{~cm}^{-1}$; MS (ESI) $\mathrm{m} / z, 454(\mathrm{M}+\mathrm{H}), 476(\mathrm{M}+\mathrm{Na})$; Anal. Calcd for $\mathrm{C}_{19} \mathrm{H}_{43} \mathrm{NOSSn}$ : C, 50.45; H, 9.58; N, 3.10. Found: C, 50.23; H, 9.36; N, 3.12. $\left(S_{S}, R\right)-N$-(1-Tributylstannyl-2-methylpropyl)-t-butanesulfinamide (5c)

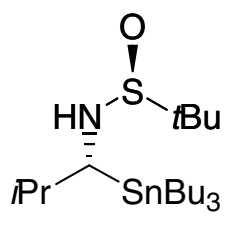

$[\alpha]_{\mathrm{D}}=+18.0\left(\mathrm{c} 1.0, \mathrm{CHCl}_{3}\right) ;{ }^{1} \mathrm{H} \mathrm{NMR}\left(300 \mathrm{MHz}, \mathrm{CDCl}_{3}\right) \delta 3.30(2 \mathrm{H}, \mathrm{m}), 2.26(1 \mathrm{H}$, dsept, $\mathrm{J}=3.0,6.7$ Hz), 1.45-1.42 (6H, m), 1.30-1.23 (6H, m), $1.15(9 \mathrm{H}, \mathrm{s}), 0.93(3 \mathrm{H}, \mathrm{d}, \mathrm{J}=6.7 \mathrm{~Hz}), 0.90-0.81(18 \mathrm{H}, \mathrm{m})$; ${ }^{13} \mathrm{C}$ NMR (75 MHz, $\mathrm{CDCl}_{3}$ ) 857.2 56.0, 34.1, 29.1, 27.4, 22.6, 21.0, 20.6, 13.6, 10.3; IR (neat) 3226, 1464, $1073 \mathrm{~cm}^{-1}$; MS (ESI) m/z $468(\mathrm{M}+\mathrm{H}), 490(\mathrm{M}+\mathrm{Na})$; Anal. Calcd for $\mathrm{C}_{20} \mathrm{H}_{45} \mathrm{NOSSn}$ : C, 51.51; $\mathrm{H}$, 9.73; N, 3.00. Found: C, 51.71; H, 9.52; N, 3.05. 
$\left(S_{S}, R\right)-N$-(1-Tributylstannyl-2,2-dimethylpropyl)-t-butanesulfinamide (5d)<smiles>CCCCB(O)NC(CCCC)S(=O)CC(C)C</smiles>

$[\alpha]_{\mathrm{D}}=+7.3\left(\mathrm{c} 1.0, \mathrm{CHCl}_{3}\right) ;{ }^{1} \mathrm{H} \mathrm{NMR}\left(300 \mathrm{MHz}, \mathrm{CDCl}_{3}\right) \delta 3.26(1 \mathrm{H}, \mathrm{d}, \mathrm{J}=8.6 \mathrm{~Hz}), 3.19(1 \mathrm{H}, \mathrm{d}, \mathrm{J}=$ 8.6 Hz), 1.55-1.32 (6H, m), 1.36-1.20 (6H, m), $1.18(9 \mathrm{H}, \mathrm{s}), 0.97(9 \mathrm{H}, \mathrm{s}), 0.92-0.82(15 \mathrm{H}, \mathrm{m}) ;{ }^{13} \mathrm{C}$ NMR $\left(75 \mathrm{MHz}, \mathrm{CDCl}_{3}\right) \delta 62.5\left({ }^{1} \mathrm{~J}=361 \mathrm{~Hz}\right), 56.3,36.0,29.0\left({ }^{2} \mathrm{~J}=28 \mathrm{~Hz}\right), 28.8,27.4\left({ }^{3} \mathrm{~J}=59 \mathrm{~Hz}\right)$, 22.7, 13.5, $11.2\left({ }^{1} \mathrm{~J}=308,294 \mathrm{~Hz}\right)$; IR (neat) 3251, 1464, $1072 \mathrm{~cm}^{-1}$; MS (ESI) $\mathrm{m} / z 482(\mathrm{M}+\mathrm{H}), 504$ $(\mathrm{M}+\mathrm{Na})$; Anal. Calcd for $\mathrm{C}_{21} \mathrm{H}_{47} \mathrm{NOSSn}: \mathrm{C}, 52.51 ; \mathrm{H}, 9.86 ; \mathrm{N}, 2.92$. Found: C, 52.37; H, 9.91; N, 2.98 .

$\left(S_{S}, R\right)-N$-(1-Tributylstannylhexyl)-t-butanesulfinamide (5e)<smiles></smiles>

$[\alpha]_{\mathrm{D}}=+31.0\left(\mathrm{c} 1.0, \mathrm{CHCl}_{3}\right) ;{ }^{1} \mathrm{H} \mathrm{NMR}\left(300 \mathrm{MHz}, \mathrm{CDCl}_{3}\right) \delta 3.34(1 \mathrm{H}, \mathrm{dt}, \mathrm{J}=6.42,8.4 \mathrm{~Hz}), 3.15(1 \mathrm{H}$, $\mathrm{d}, \mathrm{J}=8.4 \mathrm{~Hz}), 1.90-1.75(2 \mathrm{H}, \mathrm{m}), 1.55-1.42(6 \mathrm{H}, \mathrm{m}), 1.35-1.20(12 \mathrm{H}, \mathrm{m}), 1.16(9 \mathrm{H}, \mathrm{s}), 0.92-0.82$ $(18 \mathrm{H}, \mathrm{m}) ;{ }^{13} \mathrm{C} \mathrm{NMR}\left(75 \mathrm{MHz}, \mathrm{CDCl}_{3}\right) \delta 55.6,48.2\left({ }^{1} \mathrm{~J}=346,331 \mathrm{~Hz}\right), 36.7,31.6,29.0\left({ }^{2} \mathrm{~J}=20 \mathrm{~Hz}\right)$, $27.6\left({ }^{2} \mathbf{J}=23 \mathrm{~Hz}\right), 27.3\left({ }^{3} \mathrm{~J}=56 \mathrm{~Hz}\right), 22.5,22.4,13.8,13.4,9.4\left({ }^{1} \mathrm{~J}=313,299 \mathrm{~Hz}\right)$; IR (neat) 3192 , 1464, $1056 \mathrm{~cm}^{-1}$; MS (ESI) m/z $496(\mathrm{M}+\mathrm{H}), 518(\mathrm{M}+\mathrm{Na})$; Anal. Calcd for $\mathrm{C}_{22} \mathrm{H}_{49} \mathrm{NOSSn}$ : C, 53.44; $\mathrm{H}$, 9.99; N, 2.83. Found: C, 53.42; H, 9.86; N, 2.76.

$\left(R_{S}, S\right)-N$-(8-Benzyloxy-1-tributylstannyloctyl)-t-butanesulfinamide (5f)<smiles>CCCCC(NB([O-])CCOCc1ccccc1)P(CCCC)CC(C)(C)C</smiles> 
$[\alpha]_{\mathrm{D}}=-23.4\left(\mathrm{c} 1.0, \mathrm{CHCl}_{3}\right) ;{ }^{1} \mathrm{H} \operatorname{NMR}\left(300 \mathrm{MHz}, \mathrm{CDCl}_{3}\right) \delta 7.30(5 \mathrm{H}, \mathrm{m}), 4.45(2 \mathrm{H}, \mathrm{s}), 3.42(2 \mathrm{H}, \mathrm{t}, \mathrm{J}=$ $6.6 \mathrm{~Hz}), 3.33(1 \mathrm{H}, \mathrm{dt}, \mathrm{J}=6.3,8.4 \mathrm{~Hz}), 3.15(1 \mathrm{H}, \mathrm{d}, \mathrm{J}=8.4 \mathrm{~Hz}), 1.90-1.75(2 \mathrm{H}, \mathrm{m}), 1.63-1.40(8 \mathrm{H}, \mathrm{m})$, 1.41-1.20 (14H, m), $1.16(9 \mathrm{H}, \mathrm{s}), 0.91-0.83(15 \mathrm{H}, \mathrm{m}) ;{ }^{13} \mathrm{C}$ NMR $\left(75 \mathrm{MHz}, \mathrm{CDCl}_{3}\right)$ 8138.6, 128.2, 127.5, 127.3, 72.7, 70.2, 55.7, 48.3, 36.8, 29.6, 29.4, 29.2, 29.1, 28.0, $27.4\left({ }^{3} \mathrm{~J}=55 \mathrm{~Hz}\right), 22.6,22.2$, 13.6, $9.5\left({ }^{1} \mathrm{~J}=313,299 \mathrm{~Hz}\right)$; IR (neat) 3196, 1455, 1362, $1073 \mathrm{~cm}^{-1}$; MS (ESI) $\mathrm{m} / \mathrm{z} 630(\mathrm{M}+\mathrm{H}), 652$ $(\mathrm{M}+\mathrm{Na})$; Anal. Calcd for $\mathrm{C}_{31} \mathrm{H}_{59} \mathrm{NO}_{2} \mathrm{SSn}$ : C, 59.23; H, 9.46; N, 2.23. Found: C, 59.22; H, 9.23; N, 2.15 .

$\left(S_{S}, R\right)-N$-(1-Tributylstannyl-1-cyclohexylmethyl)-t-butanesulfinamide (5g)

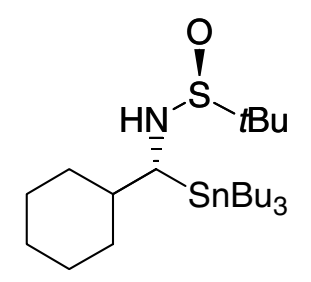

$[\alpha]_{\mathrm{D}}=-2.6\left(\mathrm{c} 1.0, \mathrm{CHCl}_{3}\right) ;{ }^{1} \mathrm{H} \mathrm{NMR}\left(300 \mathrm{MHz}, \mathrm{CDCl}_{3}\right) \delta 3.28(2 \mathrm{H}, \mathrm{s}), 1.92-1.18(23 \mathrm{H}, \mathrm{m}), 1.14(9 \mathrm{H}$, s), 1.00-0.79 (15H, m); ${ }^{13} \mathrm{C}$ NMR $\left(75 \mathrm{MHz}, \mathrm{CDCl}_{3}\right) \delta 56.2,55.9,44.2,32.0\left({ }^{2} \mathrm{~J}=30 \mathrm{~Hz}\right), 31.1,29.1\left({ }^{2} \mathrm{~J}\right.$ = $19 \mathrm{~Hz}), 27.4\left({ }^{3} \mathrm{~J}=58 \mathrm{~Hz}\right), 26.2,26.1,22.6,13.5,10.3\left({ }^{1} \mathrm{~J}=311,298 \mathrm{~Hz}\right)$; IR (neat) 3234, 1449, $1072 \mathrm{~cm}^{-1}$; MS (ESI) m/z $508(\mathrm{M}+\mathrm{H}), 530(\mathrm{M}+\mathrm{Na})$; Anal. Calcd for $\mathrm{C}_{23} \mathrm{H}_{49} \mathrm{NOSSn}: \mathrm{C}, 54.55 ; \mathrm{H}, 9.75$; N, 2.77. Found: C, 54.70; H, 9.50; N, 2.74.

General procedure for the synthesis of enantiomerically enriched $\alpha$-benzamidostannanes 6 . Into a flame dried round bottom flask equipped with a stir bar was weighed the sulfinamide $5(0.18 \mathrm{mmol})$. The flask was then charged with dry THF ( $3 \mathrm{~mL}$ ) while being kept under argon, and then cooled to $78{ }^{\circ} \mathrm{C} . n$-Butyllithium $(1.6 \mathrm{M}, 0.27 \mathrm{mmol}, 1.5 \mathrm{eq})$ was then added via syringe, and the solution stirred for $15 \mathrm{~min}$. Benzoic anhydride $(0.54 \mathrm{mmol}, 3 \mathrm{eq})$ was dissolved in dry THF $(0.5 \mathrm{~mL})$ and added rapidly to the sulfinamide solution. The solution was allowed to warm to room temperature, and then stirred for $1 \mathrm{~h}$. The reaction was quenched with saturated aqueous sodium bicarbonate $(3 \mathrm{~mL})$, diluted 
with diethyl ether $(30 \mathrm{~mL})$ and water $(5 \mathrm{~mL})$, and the ether layer washed with $1 \mathrm{M}$ sodium hydroxide solution $(10 \mathrm{~mL})$ and then brine $(10 \mathrm{~mL})$. The ether layer was then dried with sodium sulfate, and filtered through a pad of Celite ${ }^{\circledR}$. The ether layer was evaporated under reduced pressure to afford the $N$-benzoyl $\alpha$-sulfinamidostannanes as a clear colorless oil, which was purified via flash column chromatography ( $30 \mathrm{~g}$ of silica/g of crude material, 10:1 hexane:ethyl acetate).

The acyl sulfinamide $(0.20 \mathrm{mmol})$ was weighed into a round bottom flask equipped with a stir bar and argon line and dissolved in dry methanol $(2.5 \mathrm{~mL})$. Concentrated $\mathrm{HCl}(0.5 \mathrm{~mL})$ was added dropwise, and the solution stirred at room temperature for $30 \mathrm{~min}$. The reaction was quenched with saturated sodium bicarbonate $(10 \mathrm{~mL})$, and diluted with $\mathrm{CH}_{2} \mathrm{Cl}_{2}(30 \mathrm{~mL})$ and water $(5 \mathrm{~mL})$. The $\mathrm{CH}_{2} \mathrm{Cl}_{2}$ layer was washed with saturated sodium bicarbonate $(10 \mathrm{~mL})$ and then brine $(10 \mathrm{~mL})$, dried with sodium sulfate, and filtered through a pad of Celite ${ }^{\circledR}$. The $\mathrm{CH}_{2} \mathrm{Cl}_{2}$ was evaporated under reduced pressure to afford a clear colorless oil which was purified via flash column chromatography (30 $\mathrm{g}$ of silica/g of crude material, 10:1 hexane:ethyl acetate).

General procedure for the synthesis of racemic $\alpha$-benzamidostannanes $( \pm)-6$. To a cooled $\left(0{ }^{\circ} \mathrm{C}\right)$ $0.5 \mathrm{M}$ solution of diisopropylamine $(1 \mathrm{mmol}, 1 \mathrm{eq})$ in THF was added $n \mathrm{BuLi}(1 \mathrm{mmol}, 1 \mathrm{eq})$ dropwise, and the resulting solution was stirred for $15 \mathrm{~min} . \mathrm{Bu}_{3} \mathrm{SnH}(1 \mathrm{mmol}, 1 \mathrm{eq})$ was then added dropwise, and the solution was stirred for another $15 \mathrm{~min}$. The resulting slightly yellowish solution of $\mathrm{Bu}_{3} \mathrm{SnLi}$ was then cooled to $-78{ }^{\circ} \mathrm{C}$ and the appropriate aldehyde $(1 \mathrm{mmol}, 1 \mathrm{eq})$ was added dropwise. The reaction was stirred at $-78{ }^{\circ} \mathrm{C}$ for 30 min., quenched with saturated aqueous $\mathrm{NH}_{4} \mathrm{Cl}(20 \mathrm{~mL})$, and

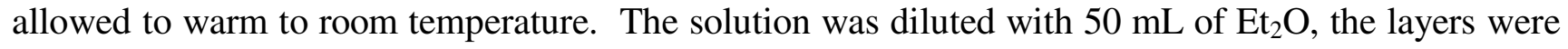
separated, and the aqueous layer washed with $20 \mathrm{~mL}$ of $\mathrm{Et}_{2} \mathrm{O}$. The organic layers were washed with brine (20 mL), dried with $\mathrm{MgSO}_{4}$, filtered, and concentrated in vacuo (room temperature water bath) to afford the crude $\alpha$-hydroxystannane as a colorless oil. 
The crude hydroxystannane was made as a $0.5 \mathrm{M}$ solution in $\mathrm{THF}$, and cooled to $0{ }^{\circ} \mathrm{C}$. To the cooled solution was added phthalimide $(1.3 \mathrm{mmol}, 1.3 \mathrm{eq})$, and triphenylphosphine (1.3 mmol, 1.3 eq). A $3 \mathrm{M}$ solution of $\mathrm{DEAD}(1.3 \mathrm{mmol}, 1.3 \mathrm{eq})$ in THF was then added dropwise slowly to the stirring solution through a dropping funnel. The cooling bath was removed and the solution stirred at room temperature for $30 \mathrm{~min}$. The THF was removed in vacuo and the resulting yellow oil extracted 4 times with $30 \mathrm{~mL}$ each of hexanes. The combined hexanes extracts were washed with a small amount $(10 \mathrm{~mL})$ of acetonitrile and then concentrated in vacuo to give the stannyl phthalimide as a yellow oil which was purified via flash column chromatography (20 g silica/ g substrate, 2-10\% diethyl ether/hexanes). ${ }^{5}$

The appropriate phthalimide $(0.30 \mathrm{mmol})$ was weighed into a round bottom flask equipped with a stir bar and argon line, and dissolved in ethanol $(7 \mathrm{~mL})$. Water (3 drops) was added to the solution, followed by hydrazine monohydrate $(9.0 \mathrm{mmol}, 30 \mathrm{eq})$, and the solution was refluxed for 4 hours. The ethanol was evaporated under reduced pressure and the residue dissolved in diethyl ether $(40 \mathrm{~mL})$. The ether layer was washed with brine $(10 \mathrm{~mL})$, dried with sodium sulfate, filtered through a pad of Celite ${ }^{\circledR}$ and evaporated under reduced pressure to afford the crude $\alpha$-aminostannane as a clear colorless oil.

The crude $\alpha$-aminostannane was dissolved in dry $\mathrm{CH}_{2} \mathrm{Cl}_{2}(5 \mathrm{~mL})$ and added to a dry round bottom flask equipped with a stir bar and argon line. The solution was cooled to $0{ }^{\circ} \mathrm{C}$ and triethylamine ( $0.60 \mathrm{mmol}, 2 \mathrm{eq})$ was added, followed by benzoyl chloride $(0.45 \mathrm{mmol}, 1.5 \mathrm{eq})$, and finally DMAP (0.03 mmol, $0.1 \mathrm{eq})$. The solution was allowed to warm to room temperature and stirred overnight. The reaction was quenched with saturated sodium bicarbonate $(2 \mathrm{~mL})$. The solution was diluted with $\mathrm{CH}_{2} \mathrm{Cl}_{2}(20 \mathrm{~mL})$, and the $\mathrm{CH}_{2} \mathrm{Cl}_{2}$ layer was washed with $1 \mathrm{M} \mathrm{NaOH}(10$ $\mathrm{mL})$ and then brine $(10 \mathrm{~mL})$, dried with sodium sulfate, and filtered through a pad of Celite ${ }^{\circledR}$. The $\mathrm{CH}_{2} \mathrm{Cl}_{2}$ was evaporated under reduced pressure to afford a clear orange oil which was purified via 
flash column chromatography (30 g of silica/g of crude material, 10:1 hexane:ethyl acetate) to afford a clear colorless oil.

These racemic benzamides were analyzed by HPLC $(4.6 \times 250 \mathrm{~mm}$ ChiralCel OD, $0.25-$ $2.5 \% i \mathrm{PrOH} / \mathrm{Hexane})$ in order to separate the two enantiomers. Details are shown in the following Table.

\begin{tabular}{|c|c|c|c|c|}
\hline $\mathbf{R}$ & $\begin{array}{c}\text { Solvent (\% } \\
i \text { PrOH/Hexane) }\end{array}$ & $\begin{array}{l}\text { Flow rate } \\
(\mathrm{mL} / \mathrm{min})\end{array}$ & $\begin{array}{c}\text { Retention time } \\
\text { of } 1^{\text {st }} \\
\text { enantiomer } \\
\text { eluted (min) }\end{array}$ & $\begin{array}{c}\text { Retention time } \\
\text { of } 2^{\text {nd }} \\
\text { enantiomer } \\
\text { eluted (min) }\end{array}$ \\
\hline $\operatorname{Me}(\mathbf{6 a})$ & 1.0 & 1.0 & $10.34(S)$ & $17.16(R)$ \\
\hline Et $(\mathbf{6} \mathbf{b})$ & 1.0 & 1.0 & $8.59(S)$ & $9.53(R)$ \\
\hline$i-\operatorname{Pr}(\mathbf{6 c})$ & 1.0 & 1.0 & $6.83(R)$ & $7.81(S)$ \\
\hline$n-\mathrm{C}_{5} \mathrm{H}_{11}(\mathbf{6 e})$ & 1.0 & 1.0 & $7.19(S)$ & $8.66(R)$ \\
\hline $\mathrm{BnO}\left(\mathrm{CH}_{2}\right)_{7}(\mathbf{6 f})$ & 2.5 & 1.0 & $12.05(S)$ & $14.76(R)$ \\
\hline$c-\mathrm{C}_{6} \mathrm{H}_{11}(\mathbf{6 g})$ & 0.25 & 0.5 & $20.18(S)$ & $21.58(R)$ \\
\hline
\end{tabular}

Authentic samples of enantiomerically enriched $\mathbf{6 b}, \mathbf{6 c}$, and $\mathbf{6 e}$ of known absolute configuration $^{5}$ were prepared and co-injected with racemic mixtures to determine the order of elution. In all cases, except $\mathrm{R}=i$-Pr, the $R$-enantiomer eluted second. Absolute configurations were assigned on the basis of relative elution times. The rotations of the sulfinamides $\mathbf{5}$ and of the final N-Boc aminostannanes $\mathbf{8}$ are also internally consistent with the assigned configurations (See Table below). Only the cyclohexyl series, which shows low rotations, is anomalous.

\begin{tabular}{|c|c|c|}
\hline \multirow{2}{*}{$\mathbf{R}$} & \multicolumn{3}{|c|}{ Optical Rotation $[\alpha]_{\mathbf{D}}(\mathbf{c}$ 1.0, CHCl $\mathbf{3})$} \\
\cline { 2 - 3 } & Sulfinamide 5 & $\boldsymbol{N}$-Boc Aminostannane 8 \\
\hline $\mathrm{Me}$ & $+51.2\left(S_{\mathrm{S}}, R\right)$ & $+37.0(R)$ \\
\hline $\mathrm{Et}$ & $+35.1\left(S_{\mathrm{S}}, R\right)$ & $+21.4(R)$ \\
\hline$i-\mathrm{Pr}$ & $+18.0\left(S_{\mathrm{S}}, R\right)$ & $+5.6(R)$ \\
\hline$n-\mathrm{C}_{5} \mathrm{H}_{11}$ & $+31.0\left(S_{\mathrm{S}}, R\right)$ & $+23.3(R)$ \\
\hline$c-\mathrm{C}_{6} \mathrm{H}_{11}$ & $-2.6\left(S_{\mathrm{S}}, R\right)$ & $-1.9(R)$ \\
\hline $\mathrm{BnO}\left(\mathrm{CH}_{2}\right)_{7}$ & $-23.4\left(R_{\mathrm{S}}, S\right)$ & $-18.2(S)$ \\
\hline
\end{tabular}


General procedure for the synthesis of $N$-Boc $\alpha$-sulfinamidostannanes 7 . Into a flame dried round bottom flask equipped with a stir bar was weighed di-tert-butyl dicarbonate (1.77 mmol, $3 \mathrm{eq})$. The flask was then charged with dry THF $(2.5 \mathrm{~mL})$ while being kept under argon. The solution was cooled to $0{ }^{\circ} \mathrm{C}$, following which DMAP $(1.77 \mathrm{mmol}, 3 \mathrm{eq})$ was added to the solution. The ice bath was removed and the solution allowed to stir at room temperature for $30 \mathrm{~min}$.

Into a flame dried round bottom flask equipped with a stir bar was weighed sulfinamide $\mathbf{5}$ (0.59 mmol). The flask was then charged with dry THF $(5 \mathrm{~mL})$ while being kept under argon, and then cooled to $-78{ }^{\circ} \mathrm{C}$. $n$-Butyllithium (1.6 M, $\left.1.77 \mathrm{mmol}, 3 \mathrm{eq}\right)$ was then added via syringe, and the solution stirred for $15 \mathrm{~min}$. The $\mathrm{Boc}_{2} \mathrm{O} / \mathrm{DMAP}$ solution was drawn into a syringe, and added rapidly to the sulfinamide solution, following which the $-78{ }^{\circ} \mathrm{C}$ bath was removed immediately. The solution was allowed to stir at room temperature for $1 \mathrm{~h}$, and then quenched with saturated aqueous ammonium chloride $(3 \mathrm{~mL})$. The mixture was diluted with diethyl ether $(50 \mathrm{~mL})$ and water $(10 \mathrm{~mL})$, and the ether layer washed with brine $(10 \mathrm{~mL})$, dried with sodium sulfate, and filtered through a pad of Celite ${ }^{\circledR}$. The ether layer was evaporated under reduced pressure yielding a clear orange oil, which was purified via flash column chromatography $(30 \mathrm{~g}$ of silica/g of crude material, $5-10 \%$ diethyl ether/hexane) to afford a clear colorless oil.

\section{$\left(S_{S}, R\right)-N$-Boc- $N$-(1-tributylstannylethyl)-t-butanesulfinamide (7a)}

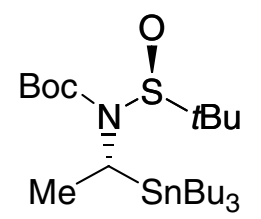

$[\alpha]_{\mathrm{D}}=-33.6\left(\mathrm{c} 1.0, \mathrm{CHCl}_{3}\right) ;{ }^{1} \mathrm{H} \mathrm{NMR}\left(300 \mathrm{MHz}, \mathrm{CDCl}_{3}\right) \delta 3.52(1 \mathrm{H}, \mathrm{q}, \mathrm{J}=7.5 \mathrm{~Hz}), 1.56-1.36(9 \mathrm{H}$, m), $1.41(9 \mathrm{H}, \mathrm{s}), 1.35-1.20(6 \mathrm{H}, \mathrm{m}), 1.17(9 \mathrm{H}, \mathrm{s}), 0.93-0.72(15 \mathrm{H}, \mathrm{m}) ;{ }^{13} \mathrm{C} \mathrm{NMR}\left(75 \mathrm{MHz}, \mathrm{CDCl}_{3}\right)$ $\delta 154.3,81.8,58.9,32.0,28.9,28.2,27.5,22.7,18.5,13.6,9.8 ;$ IR (neat) $1698,1457,1093 \mathrm{~cm}^{-1}$; MS 
(ESI) $\mathrm{m} / z, 540(\mathrm{M}+\mathrm{H}), 562(\mathrm{M}+\mathrm{Na})$; Anal. Calcd for $\mathrm{C}_{23} \mathrm{H}_{49} \mathrm{NO}_{3} \mathrm{SSn}$ : C, 51.31; H, 9.17; N, 2.60 . Found: C, 51.50; H, 9.31; N, 2.64.

$\left(S_{S}, R\right)-N$-Boc- $N$-(1-tributylstannylpropyl)-t-butanesulfinamide (7b)

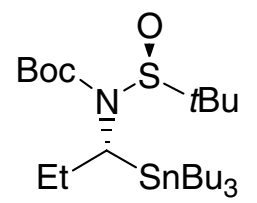

$[\alpha]_{\mathrm{D}}=-35.2\left(\mathrm{c} 1.0, \mathrm{CHCl}_{3}\right) ;{ }^{1} \mathrm{H} \mathrm{NMR}\left(300 \mathrm{MHz}, \mathrm{CDCl}_{3}\right) \delta 3.26(1 \mathrm{H}, \mathrm{dd}, \mathrm{J}=12.5,3.1 \mathrm{~Hz}), 2.21(1 \mathrm{H}$, m), 1.65-1.36 (7H, m), $1.42(9 \mathrm{H}, \mathrm{s}), 1.35-1.19(6 \mathrm{H}, \mathrm{m}), 1.16(9 \mathrm{H}, \mathrm{s}), 0.92-0.74(18 \mathrm{H}, \mathrm{m}) ;{ }^{13} \mathrm{C} \mathrm{NMR}$ $\left(75 \mathrm{MHz}, \mathrm{CDCl}_{3}\right) \delta 154.4,81.8,59.0,40.0,29.0,28.2,27.5,25.9,22.6,13.6,12.3,10.1$; IR (neat) 1698, 1458, $1092 \mathrm{~cm}^{-1}$; MS (ESI) m/z $554(\mathrm{M}+\mathrm{H}), 576(\mathrm{M}+\mathrm{Na})$; Anal. Calcd for $\mathrm{C}_{24} \mathrm{H}_{51} \mathrm{NO}_{3} \mathrm{SSn}$ : C, 52.18; H, 9.31; N, 2.54. Found: C, 51.98; H, 9.34; N, 2.55 .

$\left(S_{S}, R\right)-N$-Boc- $N$-(1-tributylstannylhexyl)-t-butanesulfinamide (7e)<smiles>CCCCCCCCCCCCCCCCCC(C)(C)C</smiles>

$[\alpha]_{\mathrm{D}}=-53.2\left(\mathrm{c} 1.0, \mathrm{CHCl}_{3}\right) ;{ }^{1} \mathrm{H} \mathrm{NMR}\left(300 \mathrm{MHz}, \mathrm{CDCl}_{3}\right) \delta 3.35(1 \mathrm{H}, \mathrm{dd}, \mathrm{J}=12.5,3.1 \mathrm{~Hz}), 2.23(1 \mathrm{H}$, m), 1.61-1.36 (7H, m), $1.43(9 \mathrm{H}, \mathrm{s}), 1.37-1.20(12 \mathrm{H}, \mathrm{m}), 1.17(9 \mathrm{H}, \mathrm{s}), 0.95-0.72(18 \mathrm{H}, \mathrm{m}) ;{ }^{13} \mathrm{C} \mathrm{NMR}$ (75 MHz, $\left.\mathrm{CDCl}_{3}\right) \delta 154.5,81.8,59.1,38.4,33.0,31.8,29.0,28.3,27.7,27.5,22.7,22.6,13.9,13.6$, 10.2; IR (neat) 1698, 1458, $1093 \mathrm{~cm}^{-1}$; MS (ESI) m/z $596(\mathrm{M}+\mathrm{H}), 618(\mathrm{M}+\mathrm{Na})$; Anal. Calcd for $\mathrm{C}_{27} \mathrm{H}_{57} \mathrm{NO}_{3} \mathrm{SSn}: \mathrm{C}, 54.55 ; \mathrm{H}, 9.66 ; \mathrm{N}, 2.36$. Found: $\mathrm{C}, 54.74 ; \mathrm{H}, 10.00 ; \mathrm{N}, 2.40$.

$\left(R_{S}, S\right)-N$-Boc- $N$-(8-Benzyloxy-1-tributylstannyloctyl)-t-butanesulfinamide (7f) 


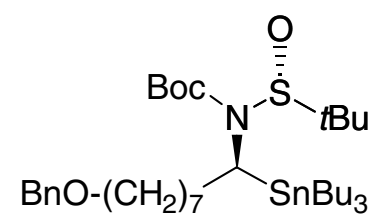

$[\alpha]_{\mathrm{D}}=+36.3\left(\mathrm{c} 1.0, \mathrm{CHCl}_{3}\right) ;{ }^{1} \mathrm{H}$ NMR $\left(300 \mathrm{MHz}, \mathrm{CDCl}_{3}\right) \delta 7.30(5 \mathrm{H}, \mathrm{m}), 4.48(2 \mathrm{H}, \mathrm{s}), 3.44(2 \mathrm{H}, \mathrm{t}, \mathrm{J}=$ 6.6 Hz), $3.36(1 \mathrm{H}, \mathrm{dd}, \mathrm{J}=12.6,2.7 \mathrm{~Hz}), 2.24(1 \mathrm{H}, \mathrm{m}), 1.67-1.39(9 \mathrm{H}, \mathrm{m}), 1.45(9 \mathrm{H}, \mathrm{s}), 1.38-1.22$ (14H, m), 1.19 (9H, s), 0.94-0.75 (15H, m); $\left.{ }^{13} \mathrm{C} \mathrm{NMR} \mathrm{(75} \mathrm{MHz,} \mathrm{CDCl}_{3}\right) \delta 154.5,138.6,128.3,127.6$, $127.4,81.8,72.8,70.4,59.1,38.3,33.0,29.7,29.6,29.5,29.0,28.3,28.0,27.5,26.1,22.7,13.7,10.2$ IR (neat) 1697, 1456, $1092 \mathrm{~cm}^{-1}$; MS (ESI) m/z $730(\mathrm{M}+\mathrm{H}), 752(\mathrm{M}+\mathrm{Na})$; Anal. Calcd for $\mathrm{C}_{36} \mathrm{H}_{67} \mathrm{NO}_{4} \mathrm{SSn}: \mathrm{C}, 59.34 ; \mathrm{H}, 9.27 ; \mathrm{N}, 1.92$. Found: C, 59.52; H, 9.10; N, 1.92.

General procedure for the synthesis of $N$-Boc $\alpha$-aminostannanes 8 from sulfinamides 7 . Into a flame dried round bottom flask equipped with a stir bar was weighed the Boc-protected sulfinamide 7 (0.17 mmol). The flask was then charged with dry THF ( $3 \mathrm{~mL})$ while being kept under argon, and then cooled to $-78{ }^{\circ} \mathrm{C}$. Methyllithium $(1.6 \mathrm{M}, 0.34 \mathrm{mmol}, 2 \mathrm{eq})$ was then added dropwise via syringe, and the solution was stirred for $15 \mathrm{~min}$. The reaction was quenched cold with saturated aqueous ammonium chloride $(2 \mathrm{~mL})$, and allowed to warm to room temperature. The mixture was diluted with diethyl ether $(20 \mathrm{~mL})$ and water $(5 \mathrm{~mL})$, and the ether layer washed with brine $(5 \mathrm{~mL})$, dried with sodium sulfate, and filtered through a pad of Celite ${ }^{\circledR}$. The ether layer was evaporated under reduced pressure to afford a clear colorless oil, which was purified via flash column chromatography (30 g of silica/g of crude material, 2-5\% diethyl ether/hexane) to afford carbamates 8 in the yields reported in Table 2.

(R)-t-Butyl $N$-(1-tributylstannylethyl)carbamate (8a)

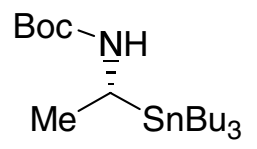


$[\alpha]_{\mathrm{D}}=+37.0\left(\mathrm{c} 1.0, \mathrm{CHCl}_{3}\right) ;{ }^{1} \mathrm{H} \mathrm{NMR}\left(300 \mathrm{MHz}, \mathrm{CDCl}_{3}\right) \delta 4.59(1 \mathrm{H}, \mathrm{d}, \mathrm{J}=7.5 \mathrm{~Hz}), 3.25(1 \mathrm{H}, \mathrm{dq}, \mathrm{J}=$ 7.5, 7.5 Hz), 1.58-1.38 (6H, m), $1.40(9 \mathrm{H}, \mathrm{s}), 1.36-1.20(9 \mathrm{H}, \mathrm{m}), 0.96-0.74(15 \mathrm{H}, \mathrm{m}) ;{ }^{13} \mathrm{C}$ NMR $(75$ $\left.\mathrm{MHz}, \mathrm{CDCl}_{3}\right) \delta 155.7,78.7,35.0,29.1,28.4,27.5,20.7,13.7,9.4 ; \mathrm{IR}$ (neat) 3352, 1702, 1500, 1366 $\mathrm{cm}^{-1}$; MS (ESI) $m / z 436(\mathrm{M}+\mathrm{H}), 458(\mathrm{M}+\mathrm{Na})$; Anal. Calcd for $\mathrm{C}_{19} \mathrm{H}_{41} \mathrm{NO}_{2} \mathrm{Sn}: \mathrm{C}, 52.55 ; \mathrm{H}, 9.52 ; \mathrm{N}$, 3.23. Found: C, $52.71 ; \mathrm{H}, 9.65 ; \mathrm{N}, 3.01$.

(R)-t-Butyl $N$-(1-tributylstannylpropyl)carbamate $(8 b)^{6}$

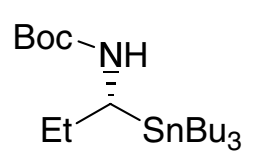

$[\alpha]_{\mathrm{D}}=+21.4\left(\mathrm{c} 1.0, \mathrm{CHCl}_{3}\right) ;{ }^{1} \mathrm{H} \mathrm{NMR}\left(300 \mathrm{MHz}, \mathrm{CDCl}_{3}\right) \delta 4.64(1 \mathrm{H}, \mathrm{d}, \mathrm{J}=7.5 \mathrm{~Hz}), 3.13(1 \mathrm{H}, \mathrm{dt}, \mathrm{J}=$ 7.5, 7.5 Hz), 1.76-1.57 (2H, m), 1.57-1.38 (6H, m), $1.40(9 \mathrm{H}, \mathrm{s}), 1.35-1.20(6 \mathrm{H}, \mathrm{m}), 0.96-0.73(18 \mathrm{H}$, $\mathrm{m}) ;{ }^{13} \mathrm{C} \mathrm{NMR}\left(75 \mathrm{MHz}, \mathrm{CDCl}_{3}\right) \delta 155.9,78.6,42.7,29.2,28.4,27.5,27.2,13.7,12.7,9.6$

$(R)$-t-Butyl $N$-(1-tributylstannylhexyl)carbamate $(8 \mathrm{e})^{6}$

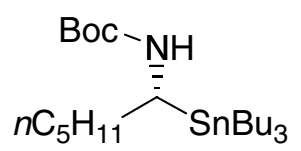

$[\alpha]_{\mathrm{D}}=+23.3\left(\mathrm{c} 1.0, \mathrm{CHCl}_{3}\right) ;{ }^{1} \mathrm{H} \mathrm{NMR}\left(300 \mathrm{MHz}, \mathrm{CDCl}_{3}\right) \delta 4.61(1 \mathrm{H}, \mathrm{d}, \mathrm{J}=7.6 \mathrm{~Hz}), 3.20(1 \mathrm{H}, \mathrm{dt}, \mathrm{J}=$ 7.2, 7.6 Hz), 1.70-1.42 (8H, m), $1.39(9 \mathrm{H}, \mathrm{s}), 1.35-1.16(12 \mathrm{H}, \mathrm{m}), 0.95-0.73(18 \mathrm{H}, \mathrm{m}) ;{ }^{13} \mathrm{C}$ NMR $(75$ $\left.\mathrm{MHz}, \mathrm{CDCl}_{3}\right) \delta 155.9,78.6,40.9,34.9,31.6,29.2,28.4,27.8,27.5,22.6,14.0,13.7,9.7$

(R)-t-Butyl $N$-(8-benzyloxy-1-tributylstannyloctyl)carbamate (8f)

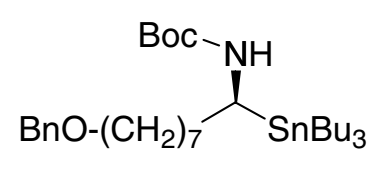

$[\alpha]_{\mathrm{D}}=-18.2\left(\mathrm{c}=1.0, \mathrm{CHCl}_{3}\right) ;{ }^{1} \mathrm{H} \operatorname{NMR}\left(300 \mathrm{MHz}, \mathrm{CDCl}_{3}\right) \delta 7.30(5 \mathrm{H}, \mathrm{m}), 4.62(1 \mathrm{H}, \mathrm{d}, \mathrm{J}=7.8 \mathrm{~Hz})$, $4.48(2 \mathrm{H}, \mathrm{s}), 3.44(2 \mathrm{H}, \mathrm{t}, \mathrm{J}=6.6 \mathrm{~Hz}), 3.20(1 \mathrm{H}, \mathrm{dt}, \mathrm{J}=7.8,7.1 \mathrm{~Hz}), 1.73-1.40(10 \mathrm{H}, \mathrm{m}), 1.41(9 \mathrm{H}, \mathrm{s})$, 
1.38-1.19 (14H, m), 0.96-0.73 (15H, m); ${ }^{13} \mathrm{C}$ NMR (300 MHz, $\left.\mathrm{CDCl}_{3}\right)$ 8156.0, 138.8, 128.4, 127.7, $127.5,78.7,72.9,70.6,40.9,35.0,29.8,29.5$ (2C), 29.3, 28.5, 28.2, 27.6, 26.3, 13.8, 9.8; IR (neat) 3345, 1698, 1498, $1366 \mathrm{~cm}^{-1}$; MS (ESI) $\mathrm{m} / z 626(\mathrm{M}+\mathrm{H}), 648(\mathrm{M}+\mathrm{Na})$; Anal. Calcd for $\mathrm{C}_{32} \mathrm{H}_{59} \mathrm{NO}_{3} \mathrm{Sn}$ : C, 61.54; H, 9.52; N, 2.24. Found: C, 61.60; H, 9.33; N, 2.19 .

General procedure for the synthesis of $N$-formyl $\alpha$-sulfinamidostannanes 9. Into a flame dried round bottom flask equipped with a stir bar was weighed the sulfinamide $5(0.40 \mathrm{mmol})$. The flask was then charged with dry THF ( $3 \mathrm{~mL})$ while being kept under argon, and then cooled to $-78{ }^{\circ} \mathrm{C} . n$ Butyllithium (1.6 M, $1.2 \mathrm{mmol}, 3 \mathrm{eq})$ was then added via syringe, and the solution was stirred for 15 min. Methyl formate $(1.2 \mathrm{mmol}, 3 \mathrm{eq})$ was then added as quickly as possible and the solution was stirred for $2 \mathrm{~h}$ at $-78{ }^{\circ} \mathrm{C}$. The reaction was quenched with saturated aqueous ammonium chloride $(3$ $\mathrm{mL})$, diluted with diethyl ether $(30 \mathrm{~mL})$ and water $(5 \mathrm{~mL})$, and the ether layer washed with brine (10 $\mathrm{mL}$ ). The ether layer was then dried with sodium sulfate, and filtered through a pad of Celite ${ }^{\circledR}$. The ether layer was evaporated under reduced pressure to afford a clear colorless oil, which was purified via flash column chromatography ( $30 \mathrm{~g}$ of silica/g of crude material, 10:1 hexane:ethyl acetate).

$\left(S_{S}, R\right)-N$-Formyl- $N$-(1-tributylstannyl-2-methylpropyl)-t-butanesulfinamide (9c)<smiles>CCCCC(C)C(C)C</smiles>

$[\alpha]_{\mathrm{D}}=-53.0\left(\mathrm{c} 1.0, \mathrm{CHCl}_{3}\right) ;{ }^{1} \mathrm{H} \mathrm{NMR}\left(300 \mathrm{MHz}, \mathrm{CDCl}_{3}\right) \delta 8.57(1 \mathrm{H}, \mathrm{s}), 2.54(1 \mathrm{H}, \mathrm{d}, \mathrm{J}=9.4 \mathrm{~Hz}), 2.31$ $(1 \mathrm{H}, \mathrm{m}), 1.43(6 \mathrm{H}, \mathrm{m}), 1.41-1.22(6 \mathrm{H}, \mathrm{m}), 1.23(9 \mathrm{H}, \mathrm{s}), 1.02(3 \mathrm{H}, \mathrm{d}, \mathrm{J}=6.6 \mathrm{~Hz}), 0.95-0.79(18 \mathrm{H}, \mathrm{m})$; ${ }^{13} \mathrm{C}$ NMR $\left(75 \mathrm{MHz}, \mathrm{CDCl}_{3}\right) \delta 161.9,59.7,53.6,30.9,29.0,27.5,21.8,21.4,21.0,13.6,11.9$; IR (neat) 1660, 1463, $1098 \mathrm{~cm}^{-1}$; MS (ESI) m/z $496(\mathrm{M}+\mathrm{H}), 518(\mathrm{M}+\mathrm{Na})$; Anal. Calcd for $\mathrm{C}_{21} \mathrm{H}_{45} \mathrm{NO}_{2} \mathrm{SSn}: \mathrm{C}$, 51.02; H, 9.17; N, 2.83. Found: C, 50.93; H, 9.05; N, 2.76.

$\left(S_{S}, R\right)-N$-Formyl- $N$-(1-tributylstannyl-1-cyclohexylmethyl)-t-butanesulfinamide $(9 \mathrm{~g})$ 


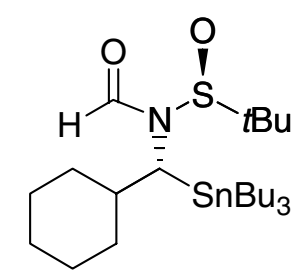

$[\alpha]_{\mathrm{D}}=+52.2\left(\mathrm{c} 1.0, \mathrm{CHCl}_{3}\right) ;{ }^{1} \mathrm{H} \mathrm{NMR}\left(300 \mathrm{MHz}, \mathrm{CDCl}_{3}\right) \delta 8.56(1 \mathrm{H}, \mathrm{s}), 2.56(1 \mathrm{H}, \mathrm{d}, \mathrm{J}=9.5 \mathrm{~Hz}), 1.92$

$(2 \mathrm{H}, \mathrm{m}), 1.80-1.36(11 \mathrm{H}, \mathrm{m}), 1.35-1.22(10 \mathrm{H}, \mathrm{m}), 1.22(9 \mathrm{H}, \mathrm{s}), 0.94-0.76(15 \mathrm{H}, \mathrm{m}) ;{ }^{13} \mathrm{C}$ NMR $(300$ $\left.\mathrm{MHz}, \mathrm{CDCl}_{3}\right) \delta 161.9,59.6,52.8,40.0,32.2,31.5,29.0,27.4,26.4,26.2,26.0,21.8,13.6,11.9 ; \mathrm{IR}$ (neat) 1659, 1461, $1099 \mathrm{~cm}^{-1}$; MS (ESI) $\mathrm{m} / z 536(\mathrm{M}+\mathrm{H}), 558(\mathrm{M}+\mathrm{Na})$; Anal. Calcd for $\mathrm{C}_{24} \mathrm{H}_{49} \mathrm{NO}_{2} \mathrm{SSn}: \mathrm{C}$, 53.94; H, 9.24; N, 2.62. Found: C, 54.04; H, 9.15; N, 2.64.

General procedure for the synthesis of $\alpha$-formamidostannanes 10. The formyl sulfinamide 9 (0.22 mmol) was weighed into a round bottom flask equipped with a stir bar and argon line and dissolved in dry methanol $(2.5 \mathrm{~mL})$. Concentrated $\mathrm{HCl}(0.5 \mathrm{~mL})$ was added dropwise, and the solution was stirred at room temperature for $4 \mathrm{~h}$. The reaction was quenched with saturated sodium bicarbonate $(5 \mathrm{~mL})$, and diluted with $\mathrm{CH}_{2} \mathrm{Cl}_{2}(30 \mathrm{~mL})$ and water $(5 \mathrm{~mL})$. The $\mathrm{CH}_{2} \mathrm{Cl}_{2}$ layer was washed with saturated sodium bicarbonate $(10 \mathrm{~mL})$ and then brine $(10 \mathrm{~mL})$, dried with sodium sulfate, and filtered through a pad of Celite ${ }^{\circledR}$. The $\mathrm{CH}_{2} \mathrm{Cl}_{2}$ was evaporated under reduced pressure to afford a clear colorless oil which was purified via flash column chromatography (30 $\mathrm{g}$ of silica/g of crude material, 5:1 hexane:ethyl acetate).

(R)-N-(1-Tributylstannyl-2-methylpropyl)formamide (10c)<smiles>CCCCC(C)C(C)C</smiles>

$[\alpha]_{\mathrm{D}}=+44.8\left(\mathrm{c} 1.0, \mathrm{CHCl}_{3}\right) ;{ }^{1} \mathrm{H} \mathrm{NMR}\left(300 \mathrm{MHz}, \mathrm{CDCl}_{3}\right) \delta 8.09(1 \mathrm{H}, \mathrm{s}), 5.98(1 \mathrm{H}, \mathrm{d}, \mathrm{J}=8.1 \mathrm{~Hz}), 3.30$ $(1 \mathrm{H}, \mathrm{dd}, \mathrm{J}=8.0,8.1 \mathrm{~Hz}), 2.00(1 \mathrm{H}, \mathrm{m}), 1.57-1.13(15 \mathrm{H}, \mathrm{m}), 0.95-0.76(18 \mathrm{H}, \mathrm{m}) ;{ }^{13} \mathrm{C} \mathrm{NMR}(75 \mathrm{MHz}$, $\left.\mathrm{CDCl}_{3}\right) \delta 160.4,46.7,31.8,29.1,27.5,21.6,20.8,13.6,10.3$; IR (neat) $3251,1649,1375 \mathrm{~cm}^{-1}$; MS 
(ESI) $m / z 414(\mathrm{M}+\mathrm{Na})$; Anal. Calcd for $\mathrm{C}_{17} \mathrm{H}_{37} \mathrm{NOSn}$ : C, 52.33; H, 9.56; N, 3.59. Found: C, 52.48; H,

$9.38 ; \mathrm{N}, 3.56$.

(R)-N-(1-Tributylstannyl-1-cyclohexylmethyl)formamide (10g)<smiles>CCCCC(NC=O)C1CCCCC1</smiles>

$[\alpha]_{\mathrm{D}}=-29.7\left(\mathrm{c} 1.0, \mathrm{CHCl}_{3}\right) ;{ }^{1} \mathrm{H}$ NMR $\left(300 \mathrm{MHz}, \mathrm{CDCl}_{3}\right) \delta 8.11(1 \mathrm{H}, \mathrm{s}), 5.69(1 \mathrm{H}, \mathrm{d}, \mathrm{J}=8.3 \mathrm{~Hz}), 3.35$

$(1 \mathrm{H}, \mathrm{dd}, \mathrm{J}=8.1,8.1 \mathrm{~Hz}), 1.81-1.03(23 \mathrm{H}, \mathrm{m}), 0.97-0.76(15 \mathrm{H}, \mathrm{m}) ;{ }^{13} \mathrm{C} \mathrm{NMR}\left(75 \mathrm{MHz}, \mathrm{CDCl}_{3}\right) \delta 160.4$ 45.8, 41.4, 32.4, 31.6, 29.2, 27.5, 26.3, 26.1, 13.7, 10.4; IR (neat) 3248, 1649, $1376 \mathrm{~cm}^{-1}$; MS (ESI) $\mathrm{m} / z$ $454(\mathrm{M}+\mathrm{Na})$; Anal. Calcd for $\mathrm{C}_{20} \mathrm{H}_{41} \mathrm{NOSn}: \mathrm{C}, 55.83 ; \mathrm{H}, 9.60 ; \mathrm{N}, 3.26$. Found: C, 58.15; H, 10.00; N, 3.11 .

General procedure for the synthesis of $N$-Boc $\alpha$-formamidostannanes 11. Into a flame dried round bottom flask equipped with a stir bar was weighed the formamidostannane $\mathbf{1 0}(0.24 \mathrm{mmol})$. The flask was then charged with dry acetonitrile $(10 \mathrm{~mL})$ while being kept under argon, and cooled to $0{ }^{\circ} \mathrm{C}$. Boc $_{2} \mathrm{O}(0.48 \mathrm{mmol}, 2 \mathrm{eq})$ was added to the solution, followed by triethylamine $(0.72 \mathrm{mmol}, 3$ eq) and finally DMAP (0.024 mmol, $0.1 \mathrm{eq})$. The ice bath was removed and the solution was stirred at room temperature overnight. The mixture was extracted 3 times with hexane $(15 \mathrm{~mL}, 45 \mathrm{~mL}$ in total), and the combined hexane layers were washed with brine $(10 \mathrm{~mL})$, dried with sodium sulfate, and filtered through a pad of Celite ${ }^{\circledR}$. The solvent was evaporated under reduced pressure to afford a clear yellowish oil, which was purified via flash column chromatography $(30 \mathrm{~g}$ of silica/g of crude material, $10 \%$ diethyl ether/hexane).

(R)- $N$-Boc- $N$-(1-Tributylstannyl-2-methylpropyl)formamide (11c) 


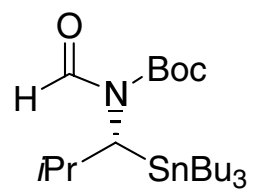

$[\alpha]_{\mathrm{D}}=-45.3\left(\mathrm{c} 1.0, \mathrm{CHCl}_{3}\right) ;{ }^{1} \mathrm{H} \mathrm{NMR}\left(300 \mathrm{MHz}, \mathrm{CDCl}_{3}\right) \delta 9.19(1 \mathrm{H}, \mathrm{s}), 2.22(1 \mathrm{H}, \mathrm{m}), 1.65-1.37(7 \mathrm{H}$, m), $1.51(9 \mathrm{H}, \mathrm{s}), 1.35-1.19(6 \mathrm{H}, \mathrm{m}), 1.11-0.72(21 \mathrm{H}, \mathrm{m}) ;{ }^{13} \mathrm{C} \mathrm{NMR}\left(300 \mathrm{MHz}, \mathrm{CDCl}_{3}\right) \delta 163.4,153.2$, 83.6, 29.1, 28.0, 27.9, 27.5, 21.6, 20.2, 13.7, 10.7, 10.1; IR (neat) 2115, 1733, $1679 \mathrm{~cm}^{-1}$; MS (ESI) $\mathrm{m} / \mathrm{z}$ $492(\mathrm{M}+\mathrm{H}), 514(\mathrm{M}+\mathrm{Na})$; Anal. Calcd for $\mathrm{C}_{22} \mathrm{H}_{45} \mathrm{NO}_{3} \mathrm{Sn}$ : C, 53.89; H, 9.25; N, 2.86. Found: C, 54.01; H, 9.14; N, 2.91 .

(R)-N-Boc- $N$-(1-Tributylstannyl-1-cyclohexylmethyl)formamide (11g)

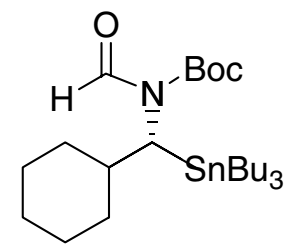

$[\alpha]_{\mathrm{D}}=+47.4\left(\mathrm{c} 1.0, \mathrm{CHCl}_{3}\right) ;{ }^{1} \mathrm{H}$ NMR $\left(300 \mathrm{MHz}, \mathrm{CDCl}_{3}\right) \delta 9.18(1 \mathrm{H}, \mathrm{s}), 2.00-0.96(24 \mathrm{H}, \mathrm{m}), 1.50(9 \mathrm{H}$, s), 0.96-0.68 (15H, m); ${ }^{13} \mathrm{C}$ NMR $\left(75 \mathrm{MHz}, \mathrm{CDCl}_{3}\right) \delta 163.4,153.2,83.6,38.3,32.4,30.8,28.9,28.0$, 27.4, 26.5, 26.2, 25.8, 13.7, 10.7, 10.1; IR (neat) 2114, 1732, $1682 \mathrm{~cm}^{-1}$; MS (ESI) $\mathrm{m} / \mathrm{z} 532(\mathrm{M}+\mathrm{H})$, $554(\mathrm{M}+\mathrm{Na})$; Anal. Calcd for $\mathrm{C}_{25} \mathrm{H}_{49} \mathrm{NO}_{3} \mathrm{Sn}: \mathrm{C}, 56.61 ; \mathrm{H}, 9.31 ; \mathrm{N}, 2.64$. Found: $\mathrm{C}, 56.81 ; \mathrm{H}, 9.17 ; \mathrm{N}$, 2.74 .

General procedure for the synthesis of $N$-Boc $\alpha$-aminostannanes 8 from formamides 11. Into a round bottom flask equipped with a stir bar was weighed the Boc-protected formamide 11 (0.10 mmol), which was then dissolved in ethanol ( $5 \mathrm{~mL})$. A few drops of water were added to the solution, followed by hydrazine monohydrate $(3.0 \mathrm{mmol}, 30 \mathrm{eq})$. The solution was refluxed under argon for 2 h. The ethanol was evaporated under reduced pressure, and the residue dissolved in diethyl ether (30 $\mathrm{mL})$. The ether layer was washed with water $(10 \mathrm{~mL})$, saturated ammonium chloride $(10 \mathrm{~mL})$, and then brine $(10 \mathrm{~mL})$. The ether was dried with sodium sulfate and filtered through a pad of Celite ${ }^{\circledR}$, 
and then evaporated under reduced pressure to afford a clear colorless oil, which was purified via flash column chromatography (30 $\mathrm{g}$ of silica/g of crude material, 2-5\% diethyl ether/hexane).

(R)-t-Butyl $N$-(1-tributylstannyl-2-methylpropyl)carbamate $(8 \mathrm{c})^{5}$

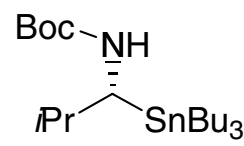

$[\alpha]_{\mathrm{D}}=+5.6\left(\mathrm{c} 1.0, \mathrm{CHCl}_{3}\right) ;{ }^{1} \mathrm{H} \mathrm{NMR}\left(300 \mathrm{MHz}, \mathrm{CDCl}_{3}\right) \delta 4.69(1 \mathrm{H}, \mathrm{d}, \mathrm{J}=8.4 \mathrm{~Hz}), 3.08(1 \mathrm{H}, \mathrm{dd}, \mathrm{J}=$ 7.5, 8.4 Hz), $1.95(1 \mathrm{H}, \mathrm{m}), 1.59-1.39(6 \mathrm{H}, \mathrm{m}), 1.40(9 \mathrm{H}, \mathrm{s}), 1.36-1.21(9 \mathrm{H}, \mathrm{m}), 1.10-0.72(18 \mathrm{H}, \mathrm{m})$;

${ }^{13} \mathrm{C}$ NMR $\left(75 \mathrm{MHz}, \mathrm{CDCl}_{3}\right)$ 156.0, 78.6, 49.0, 32.7, 29.2, 28.4, 27.6, 21.5, 20.8, 13.7, 10.2

(R)-t-Butyl $N$-(tributylstannylcyclohexylmethyl)carbamate $(8 g)^{6}$<smiles>CCCCC(NC(=O)OC(C)(C)C)C1CCCCC1</smiles>

$[\alpha]_{\mathrm{D}}=-1.9\left(\mathrm{c} 1.0, \mathrm{CHCl}_{3}\right) ;{ }^{1} \mathrm{H} \mathrm{NMR}\left(300 \mathrm{MHz}, \mathrm{CDCl}_{3}\right) \delta 4.68(1 \mathrm{H}, \mathrm{d}, \mathrm{J}=7.6 \mathrm{~Hz}), 3.11(1 \mathrm{H}, \mathrm{dd}, \mathrm{J}=$ 7.6, 8.2 Hz), 1.82-1.05 (23H, m), $1.40(9 \mathrm{H}, \mathrm{s}), 0.96-0.73(15 \mathrm{H}, \mathrm{m}) ;{ }^{13} \mathrm{C} \mathrm{NMR}\left(75 \mathrm{MHz}, \mathrm{CDCl}_{3}\right)$ $\delta 156.1,78.7,48.2,42.4,32.4,31.6,29.3,28.5,27.6,26.6,26.5,26.3,13.8,10.4$

\section{References}

1. Han, Z.; Krishnamurthy, D.; Grover, P.; Fang, Q. K.; Senanayake, C. H. J. Am. Chem. Soc. 2002, 124, 7880-7881.

2. Liu, G.; Cogan, D. A.; Ellman, J. A. J. Am. Chem. Soc. 1997, 119, 9913-9914 Supporting Information

3. Liu, G.; Cogan, D. A.; Owens, T. D.; Tang, T. P.; Ellman, J. A. J. Org. Chem. 1999, 64, 12781284. 
4. Staas, D. D.; Savage, K. L.; Homnick, C. F.; Tsou, N. N.; Ball, R. G. J. Org. Chem. 2002, 67, 8276-8279.

5. Chong, J. M.; Park, S. B. J. Org. Chem. 1992, 57, 2220-2222.

6. Ncube, A.; Park, S. B.; Chong, J. M. J. Org. Chem. 2002, 67, 3625-3636. 